\title{
EDITORIAL
}

\section{A importância de uma Revista científica na interface de Saúde e Ciências Sociais e Humanas}

A criação de um periódico pode ser vista como a abertura de mais um espaço de veiculação de produções científicas, bem como, a possibilidade de articulação de ideias de cientistas, pesquisadores, professores, discentes, profissionais e outros que queiram divulgar suas produções ou suas reflexões.

A Revista Família, Ciclos de Vida e Saúde no Contexto Social (REFACS) nasce com esta proposta e espera ao longo da história que vai construir propor espaços de debate, reflexão, comunicação, troca de experiências e contribuições científicas.

Dentre as perspectivas de abordagem que a REFACS espera abordar está a intenção de criar interfaces da área de Saúde com as Ciências Sociais e Humanas, focalizando aspectos que estão além do olhar clínico biológico do processo saúde doença, mesmo considerando que a dimensão clínica também seja importante, mas também assumindo que esta dimensão sozinha é insuficiente para dar conta da complexidade que tem o setor saúde, e mais especificamente em temas da contemporaneidade.

Um ponto também importante diz respeito, ao fato de se dar voz e vazão a produções que frequentemente são impedidas de veiculação na saúde, pelo fato de se ter um hábito de valorização da "clínica pela clínica", esquecendo-se, o quanto outras dimensões que antecipam e postergam o processo saúde doença são por vezes até mais importantes do que o simples olhar biomédico e o excesso de valorização de pesquisas nas chamadas "áreas duras" da saúde que são necessárias, mas insuficientes para dar conta da compreensão da complexa teia de significados, valores, perspectivas e desdobramentos que a qualidade de vida, a felicidade, o prazer de viver, a importância das interações sociais, entre outras temáticas, são importantes, e que ao mesmo tempo fogem da interpretação pura da dinâmica hospitalocentrica, biomédica e medicocentrada, do olhar e fazer, da qual herdamos na formação e história em saúde.

Assim, espera-se que temáticas como: vulnerabilidades, epidemiologia e ciências sociais, educação em saúde, formação e atualização na saúde, determinação social do processo saúde doença, novas tecnologias sociais aplicadas em saúde, inclusão de áreas de formação nas ciências sociais com a saúde, controle social, judicialização da saúde, metodologia de pesquisa e intervenção das ciências sociais e humanas aplicadas a saúde, acesso em saúde, políticas inclusivas, políticas sociais em saúde, geopolítica e saúde, políticas de alimentação e nutrição, perspectivas cuidativas, e tantas outras, possam ter espaço de publicização de seus saberes na REFACS.

As questões acerca de ciclos de vida, família, desenvolvimento social e humano e, contextos sociais, também serão apreciados como tópicos importantes para publicação.

A Residência Integrada Multiprofissional em Saúde (RIMS), o Grupo de Pesquisa Ciclos de Vida, Família e Saúde no Contexto Social (CIFACS) e o Núcleo de Estudos e Pesquisas sobre Envelhecimento Humano e Longevidade (NEPEHL), apresenta a REFACS e convida os vários profissionais da saúde e das ciências sociais e humanas, ou que se interessem pela área para submeterem seus manuscritos.

Um grande abraço a todos e boa leitura!

Prof. Dr. Álvaro da Silva Santos

Editor Científico da REFACS 